\title{
A Model For Promoting Active Learning And Information Literacy Skills In Large And Small Classes
}

\author{
Rhea J. Simmons, (E-mail: Rhea.Simmons@Fredonia.edu), State University of New York at Fredonia
} Marianne B. Eimer, (E-mail: Marianne.Eimer@Fredonia.edu), State University of New York at Fredonia

\begin{abstract}
Collaboration between Education and Library Instruction faculty resulted in technology being integrated into the Adolescent Development course curriculum taught at SUNY Fredonia's School of Education, fulfilling information literacy competency requirements. Our paper presents a model for the practical application of implementing information literacy components required for each SUNY campus. Our goal for an Adolescent Development course was to instruct students in the most efficient methods of library research while incorporating active learning strategies within large and small lecture classes. Collaboration between two different disciplines yielded the formulation of student exercises on subject-specific research within ERIC and PsycINFO databases. A Research Integration Project required students to compare resources, identify, and evaluate studies. By utilizing peer-assisted teaching strategies, this method fostered active learning through cooperative groups and promoted critical thinking skills. Workshop effectiveness and the Library Instruction assessment tool are discussed.
\end{abstract}

\section{Introduction}

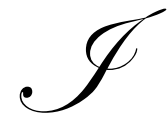

$\mathrm{n}$ an age of technological advances, students in higher education have unlimited access to information from a vast array of resources. However, the appropriate use of computer applications and data from the Internet including its apparent limitations must be stressed. Students need to be taught the proper usage of Internet resources and online databases, as essential tools for research development. The effective utilization of electronic databases and search engines to promote familiarity with scholarly research in peerreviewed or refereed journals is paramount to information literacy.

The State University of New York (SUNY) at Fredonia is a comprehensive four-year institution of higher education offering Liberal Arts and Professional programs. The college enrollment is approximately 5,000 undergraduates and 800 graduate students taught by approximately 450 faculty members. SUNY Fredonia's mission is to promote scholarly activity across disciplines by involving faculty and students in the creative process, which results in the development of critical thinking skills to facilitate lifelong learning.

Through the collaborative efforts between an Education faculty member and a Library Instruction faculty member, we were able to integrate the Information Management Competency components now required by the SUNY Board of Trustees as of 2001, into the curriculum of the course titled EDU224, Adolescent Development, via a Technology Workshop. Our goal in constructing the Technology Workshop was to instruct students in the most efficient methods of library research and computer applications that can enhance their academic studies.

This in fact coincided completely with Reed Library's philosophy of instruction, which is based on the Association for College and Research Libraries' (ACRL) Information Literacy Competency Standards for Higher Education issued in 2000. Library faculty strive to ensure that students gain the knowledge necessary to create a sophisticated search strategy, determine if they have chosen the appropriate database; evaluate the retrieved citations; and learn to retrieve scholarly articles published in peer-reviewed or refereed journals. Following this 
method encourages the development of critical thinking skills, which G. Ivan Hannel (1998) states is to "have students 'teach back' to the teacher". Howard Simmons states, "The most effective librarians in the new millennium will be those who empower learning and who facilitate the teaching and learning process."

In the case of active learning, Joan Conger (2001) tells us, "When students own the knowledge and develop skills rather than memorize... they accept responsibility for their learning process." To reflect this transition from lecture settings, in the Fall 2002, we began to incorporate active learning components, in particular peer-to-peer teaching, into our Bibliographic Instruction classes, which were easily adapted to the large classes for Adolescent Development.

\section{Course Description}

The Adolescent Development and Child Abuse Workshop Course is a three-credit 200 level psychological foundations course offered by the School of Education and is a requirement for Childhood Education majors with Middle School Extension (Grades 1 - 9) and majors in Adolescence Education (Grades 7-12). The primary focus of the Adolescent Development course is the physical, mental, and emotional influences on the human growth periods in terms of habits, interests, and social adjustment. Factors in the home and school that influence adolescent behavior and personality, individual differences, learning, and peer influences are also addressed. Applications of theory to classroom situations are stressed. In accordance with Section 3004 of the Education Law, the Child Abuse Workshop discusses the identification and reporting of suspected child abuse and maltreatment. This course meets the appropriate standards of the National Council on Accreditation of Teacher Education (NCATE) and the Association for Childhood Education International (ACEI).

Objectives of the Adolescent Development Course include the following:

- Knowledge of terms and concepts applied to adolescent development

- Knowledge of the determinants and correlates of adolescent development

- Knowledge of theoretical approaches to understanding adolescence

- Knowledge of qualitative and quantitative differences among pre-adolescents, young adolescents, and older adolescents, and the implications of these differences for promoting development, learning, and motivation

- Awareness of methods used to study adolescent development, resources available for accessing reliable research studies, and skills necessary for critical usage of published research

- Mastery of objectives subsumed under New York State Child Abuse Reporting Act

- $\quad$ Ability to convey above objectives in prescribed formats

Teacher-candidates enrolled in Adolescent Development are expected to successfully complete a Research Integration Portfolio Project. This research project is designed to provide a structured opportunity for teachercandidates to:

- $\quad$ Effectively utilize electronic databases and search engines to identify and select peer-reviewed research relevant to topics in Adolescent Development text for in-depth study

- $\quad$ Enhance familiarity with research indices and abstracts

- Develop skills in selection, evaluation, application, and integration of published research findings

- $\quad$ Accurately synthesize, evaluate, compare, and apply research findings via written report

The Research Integration Portfolio Report is divided into two parts: Part I - Preliminary Selection Report and Part II - Analysis and Synthesis. Part I requires the teacher-candidates to identify a topic of choice from the Adolescent Development text, select two research studies via the computer based indices of ERIC and PsycINFO, and summarizes the abstracts. The publications must have been written within a ten year period and include the population age range as defined by the text. Part II includes a summary of the research studies with characteristics of subjects, methodology, and outcomes. The Integrative Narrative of Part II addresses the applications, limitations, and integration of research findings with course content, and the implications of findings for teacher-student interactions, instructional planning or classroom management/discipline. Our presentation focused on how we 
addressed the skill development necessary for teacher-candidates to successfully complete Part I of the Research Integration Portfolio Project. It should be noted that if teacher-candidates were unable to appropriately complete Part I of the Project, they could not progress to the next phase, Part II. Therefore, it was essential that all teachercandidates learned, cultivated, and mastered the skills required for library research, computer applications, and information literacy.

\section{Technology Workshop}

The Technology Workshop had the following format. Each class was divided into groups, with 4 members being assigned the job functions of Navigator, Helmsman, Recorder, and Reporter. Each group was then assigned a specific topic to search and retrieve pertinent citations for, and was instructed to limit their online database searching to ERIC and PsycINFO. These topics were based on the course content and had been derived from subject areas highlighted in the course syllabus.

There were two classes in Spring 2003 that met twice for 75 minutes each, and two classes in Fall 2003, which met 3 times for 50 minutes each. Day 1 was devoted to demonstrating the ERIC and PsycINFO databases, thesaurus terms, online subject headings, and recommended search strategies. Students were instructed on retrieval options of articles, including procedures to follow in using Reed Library's Interlibrary Loan service. Students in all classes were required to locate citations and print the most relevant, including the abstract, which showed recommended subject terms and indicated their computer applications skill level. These printouts were to be consulted for their group presentations in order to recreate the search strategy followed in retrieving citations. Past searching experience within the required databases was verbally assessed. For the Spring 2003 sessions, time was allotted for in-class group work.

Time constraints eliminated in-class group work for the Fall 2003 sessions. Day 2 for the Fall 2003 classes was devoted to mastering search strategy, with further demonstration of the unique features of each database. On Day 1, in addition to the specific topic to be searched, a Search Strategy worksheet was assigned as group work, which was scheduled for presentation at the next class.

Day 2 for the Spring 2003 classes, and Day 3 for the Fall 2003 classes were devoted to the group presentations of their retrieved citations for the assigned topic, search strategies followed, problems encountered, successful problem solving, and evaluation of the citations. An assessment tool titled Library Instruction Survey was administered to all students (See Figure 1).

\section{Technology Workshop Summary Data}

The Research Integration Portfolio Project was introduced to the Adolescent Development course in the Fall 2002 semester. At that time, a one-session orientation to electronic databases and search engines was provided during class for the teacher-candidates. Based on their verbal acknowledgement of understanding the processes, a more in-depth training on search engines and profile development was not pursued. However, it became necessary to conduct twenty (20) individual tutorials with teacher-candidates who either had little to no familiarity with these computer applications or experienced difficulty with their search strategies that failed to yield any research studies. The individual tutorials required 30 minutes to 120 minutes per session outside of class, depending on the individual's level of difficulty.

In recognition of the need to provide a more comprehensive training for the teacher-candidates and resolve the apparent problem by assuming that teacher-candidates had no prior experience with the electronic databases of ERIC and PsyINFO, and profile development, the partnership between the Education and Library Instruction faculty was established. As a result, the Technology Workshop was incorporated into the curriculum of the Adolescent Development Course in the Spring 2003 semester. 
Table 1 summarizes the course sessions and enrollment (class size), number of sessions and duration of the Technology Workshop, and the number of individual tutorials that were conducted for Fall 2002, Spring 2003, and Fall 2003 semesters.

Table 1: Adolescent Development Technology Workshop Summary Data

\begin{tabular}{|c|c|c|c|c|c|}
\hline & Fall 2002 & \multicolumn{2}{|c|}{ Spring 2003} & \multicolumn{2}{|c|}{ Fall 2003} \\
\hline Session & MWF & TR & TR & MWF & MWF \\
\hline Enrollment & 51 & 29 & 51 & 70 & 36 \\
\hline $\begin{array}{l}\text { Technology } \\
\text { Workshop }\end{array}$ & No & Yes & Yes & Yes & Yes \\
\hline $\begin{array}{l}\text { Workshop } \\
\text { Duration }\end{array}$ & 0 minutes & $\begin{array}{c}2 \text { sessions } \\
75 \text { minutes each }\end{array}$ & $\begin{array}{c}2 \text { sessions } \\
75 \text { minutes each }\end{array}$ & $\begin{array}{c}3 \text { sessions } \\
50 \text { minutes each }\end{array}$ & $\begin{array}{c}3 \text { sessions } \\
50 \text { minutes each }\end{array}$ \\
\hline $\begin{array}{l}\text { Prior Online } \\
\text { Database Experience }\end{array}$ & $10 \%$ & $10 \%$ & $10 \%$ & $10 \%$ & $10 \%$ \\
\hline $\begin{array}{l}\text { \# Individual } \\
\text { Tutorials }\end{array}$ & 20 & 10 & 5 & 3 & 2 \\
\hline
\end{tabular}

\section{Assessment Tool Summary Data}

The Library Instruction Survey assessment tool was revised from the Spring 2003 semester (See Figure 1), to the Fall 2003 semester with not all categories showing results from Spring to Fall. For the Spring 2003 classes, in responding to Question 1, it was apparent that that the majority of the students, $84 \%$ in Class I and $89 \%$ in Class II, used search engines on the Internet to obtain research articles. There was an even larger group in the Fall 2003 semester, $95 \%$ of Class I and $97 \%$ of Class II, who also indicated Internet use for article retrieval.

For Question 2 which asked about newly learned material, only 52\% of Class I in the spring indicated they had gained skills for searching databases, whereas $84 \%$ of Class II students felt their skills had improved. In the fall, Class I had $97 \%$ and Class II had $83 \%$ of the student responses claiming to have acquired database searching skills. All students differentiated between database searching and web searching, with $65 \%$ of Class I, and $62 \%$ of Class II, from the spring semester indicating their web searching skills had improved. In the fall, Class I had $80 \%$ and Class II had $72 \%$ of the students claiming improvement. In response to the spring semester's Question 2, an additional skill learned mentioned was that of document retrieval, with 52\% of Class I and 66\% of Class II now indicating they understand the process to be followed and are able to accomplish this task.

For this survey (see Figure 1), Question 3 attempts to assess future research needs. Class I had 59\% and Class II had $51 \%$ of student responses wanting additional instruction about Reed Library's online databases and searching techniques. For additional Internet search strategy instruction, there was 69\% of Class I students and 39\% of Class II students looking for this help. Even though Reed's online catalog was not included in the instruction session because students were limited to retrieving scholarly articles, $45 \%$ of Class I and $41 \%$ of Class II students indicated they would like formal instruction in this area.

The last question that was included in both survey versions asked students to determine if the Technology Workshop was effective and informative. For the Spring 2003 semester, this appears as Question 4. Results were that Class I had 94\% and Class II had 91\% of the students answering in the affirmative. For the Fall 2003 semester, this appears as Question 7. Again, the instruction was considered to be effective by the majority of students attending the sessions, with $82 \%$ from Class I and 100\% from Class II claiming so on the survey.

The revised survey for Fall 2003 (see Figure 2) includes questions that now ask students to begin to think critically about the research process they have just learned. Results from Question 2 show 85\% of students in Class I and $90 \%$ of students in Class II do rank library instruction important to their overall academic success. Confidence in beginning a research paper has been boosted in $82 \%$ of students attending in Class I, and $100 \%$ of students attending in Class II, which was Question 3. We were also interested in learning if students felt they were able to apply concepts they learned in that particular session to other research assignments they might have. This was posed 
in Question 4. An overwhelming majority of students perceive this to be true, with $98 \%$ of Class I and $100 \%$ of Class II indicating an affirmative answer.

Table 2 summarizes the course sessions and enrollment (class size), number of sessions, number of completed surveys, survey questions and results that were conducted for Spring 2003 and Fall 2003 semesters.

Table 2: Assessment Tool Summary Data Library Instruction Survey

\begin{tabular}{|c|c|c|c|c|c|}
\hline Categories & \multicolumn{2}{|c|}{ Spring 2003} & \multicolumn{2}{|c|}{ Fall 2003} & Overall Total \\
\hline Session & TR & TR & MWF & MWF & Full Year Results \\
\hline Enrollment & 29 & 51 & 70 & 36 & 186 \\
\hline Completed Surveys* & $30 * *$ & 45 & 61 & 29 & 165 \\
\hline $\begin{array}{l}\text { Library Instruction Survey } \\
\text { Utilized }\end{array}$ & \multicolumn{2}{|c|}{$\begin{array}{c}\text { Figure 1 } \\
\text { Spring 2003 Survey }\end{array}$} & \multicolumn{2}{|c|}{$\begin{array}{c}\text { Figure 2 } \\
\text { Fall 2003 Survey }\end{array}$} & $\begin{array}{l}\text { Combined } \\
\text { Surveys }\end{array}$ \\
\hline $\begin{array}{l}\text { Internet Searches for } \\
\text { Research Articles }\end{array}$ & $84 \%$ & $89 \%$ & $95 \%$ & $97 \%$ & $91 \%$ \\
\hline $\begin{array}{l}\text { Skills Acquired for Database } \\
\text { Searching }\end{array}$ & $52 \%$ & $84 \%$ & $97 \%$ & $83 \%$ & $79 \%$ \\
\hline $\begin{array}{l}\text { Improvement in Search } \\
\text { Strategy Skills }\end{array}$ & $65 \%$ & $62 \%$ & $97 \%$ & $83 \%$ & $70 \%$ \\
\hline Ability to Retrieve Documents & $52 \%$ & $66 \%$ & $\begin{array}{c}\text { Not } \\
\text { included }\end{array}$ & Not included & $\begin{array}{c}\text { (Spring Only) } \\
59 \% \\
\end{array}$ \\
\hline $\begin{array}{l}\text { Technology Workshop } \\
\text { Effective \& Informative }\end{array}$ & $94 \%$ & $91 \%$ & $82 \%$ & $100 \%$ & $92 \%$ \\
\hline $\begin{array}{l}\text { Confidence to Begin Research } \\
\text { Paper }\end{array}$ & $\begin{array}{c}\text { Not } \\
\text { included }\end{array}$ & $\begin{array}{c}\text { Not } \\
\text { included }\end{array}$ & $82 \%$ & $100 \%$ & $\begin{array}{l}\text { (Fall Only) } \\
91 \%\end{array}$ \\
\hline $\begin{array}{l}\text { Ability to Apply Concepts to } \\
\text { Other Projects }\end{array}$ & $\begin{array}{c}\text { Not } \\
\text { included }\end{array}$ & $\begin{array}{c}\text { Not } \\
\text { included }\end{array}$ & $98 \%$ & $100 \%$ & $\begin{array}{c}\text { (Fall Only) } \\
99 \%\end{array}$ \\
\hline $\begin{array}{l}\text { Importance of Technology } \\
\text { Workshop to Overall } \\
\text { Academic Success }\end{array}$ & $\begin{array}{c}\text { Not } \\
\text { included }\end{array}$ & $\begin{array}{c}\text { Not } \\
\text { included }\end{array}$ & $85 \%$ & $90 \%$ & $\begin{array}{c}\text { (Fall Only) } \\
88 \%\end{array}$ \\
\hline
\end{tabular}

* Completed surveys refer to the number of students submitting surveys.

** Difference results from student withdrawal from course.

\section{Outcomes}

The incorporation of the Technology Workshop into the curriculum of the Adolescent Development course has significantly decreased the number of individual tutorials with teacher-candidates relative to the Research Integration Portfolio Project.

There are several benefits of the integration of these information literacy components. Out of the 186 students who participated in the Technology Workshop, we received 165 completed surveys, yielding an $89 \%$ return rate. Averaging the Library Instruction Survey results, we learn that $91 \%$ of our undergraduates in these classes start with the Internet to obtain scholarly research articles. Based on our Technology Workshop, 79\% now feel they have acquired sufficient skills to perform database searching within the required databases of ERIC and PsycINFO. The majority of the students, at $70 \%$, feel they have improved their searching skills as a result of this Technology Workshop. Finally, 92\% of the students perceive this workshop as effective and informative, with $99 \%$ of the students from the fall semester indicating they will be able to apply concepts to additional research projects.

Single semester results include $59 \%$ of Spring semester students that indicated knowledge of document retrieval. For Fall semester, there were $91 \%$ of respondents who indicated confidence in beginning a research paper; $99 \%$ were able to apply learned concepts to other research projects; and $88 \%$ perceived the Technology Workshop as important to their overall academic success. 
The SUNY Fredonia campus climate has also been impacted by this successful partnership. We can now identify similar instances of collaboration that incorporate the active learning strategies, including bibliographic instruction classes for Theatre Arts, History, Business, and English Composition. The exercises enhance students' recognition of the role the Library faculty plays in the academic research process. The classes reduce students' technological anxiety, fostering experimentation within and increasing familiarity of databases. Critical thinking skills are developed during the evaluation and integration of published research. Through the peer-to-peer teaching activity, the students exhibit signs of self-efficacy, owning the knowledge necessary to create valid search strategies. It appears that the students now recognize the importance and validity of research strategy skills.

\section{Summary}

The inclusion of technology in the classroom is an essential component for every teacher preparation program today. With the advent of video games and other forms of computer-generated entertainment, teachercandidates have a basic understanding of only some of the computer applications and processes. However, the practical application of computers for research development has not been fully realized by our teacher-candidates. As a result, information literacy has taken on a new meaning when it is applied to research in these contemporary times. The utilization of electronic databases and search engines for the identification of peer-reviewed or refereed publications are critical research skills that need to be learned, cultivated, and mastered by teacher-candidates. Our paper presents a model for promoting information literacy skills in both large and small classes of students via collaboration between an Education and Library Instruction faculty members. By utilizing peer-assisted teaching strategies specifically designed for an Adolescent Development course, teacher-candidates engaged in active learning through cooperative groups. These small group activities fostered critical thinking necessary for the successful completion of a Research Integration Portfolio Project in an Adolescent Development course.

The implementation of strategies and methods to promote information literacy skills was impacted by class size and meeting schedule. Seventy-five minute sessions for two days were preferable over fifty minute classes which convened three times per week. Both teacher-candidates and faculty shared this preference. Pre-established small cooperative groups were an essential component for the dynamics of the peer-assisted teaching strategies. Library Instruction Survey overall results reflected that the teacher-candidates acquired skills for searching electronic databases, improved their search strategy skills, and perceived the Technology Workshop as effective and informative. Based on the survey results and positive feedback from the teacher-candidates, the Technology Workshop model has been and will continue to be integrated into the curriculum of the School of Education's Adolescent Development course.

\section{References}

1. Cobb, N. J. (2001). Adolescence: continuity, change, and diversity ( $4^{\text {th }}$ edition). California: Mayfield Publishing Company.

2. Conger, J. E. (2001). "Wake up that back row! Interactive library instruction without hands-on student computers". The Reference Librarian, 73, pp. 309-322.

3. Cruickshank, D. (1987). Reflective teaching: The preparation of students for teaching. Reston, VA: Association of Teacher Educators.

4. Gage, N., \& Berliner, D. (1989). "Nurturing the critical, practical, and artistic thinking of teachers". Phi Delta Kappan, 71, pp. 212-214.

5. Hannel, G. I., \& Hannel, L. (1998, September). "Seven steps to teach critical thinking”. Education Digest, 64(1), pp. 47-51.

6. Miglietti, C. (1998, Summer). "Learning styles, classroom environment preferences, teaching styles and remedial course outcomes". Community College Review, 26(1).

7. Schon, D. (1983). The reflective practitioner: How professionals think in action. New York: Basic Books.

8. $\quad$ Schreiber, A. (1988, October). "Fire up those brain cells". Instructor, 98, 2-64.

9. Simmons, H. L. (2000). "Librarian as teacher: A personal view". College and Undergraduate Libraries, 6(2), pp. 41-44. 
10. State University of New York at Fredonia. (2003). College catalog: 2003-2005. Fredonia, New York: Author.

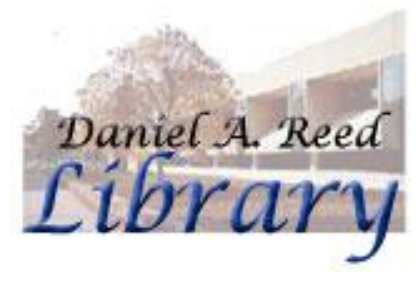

\section{Figure 1 \\ Library Instruction Survey \\ Spring 2003 \\ LIBRARY INSTRUCTION SURVEY}

Library Instructor:

Class/Day/Session:

\section{Date:}

1. Are you using the Internet to find research articles?

If yes, which search engine do you use $($ Yahoo, Google, ...)

2. What was it that you learned today that you didn't know before?
a.

b.

c.

3. What would you like to learn more about:
a. Reed's online databases and search strategies
b. Internet searching strategies
c. Searching Reed's online catalog
d. List other requests

4. Please describe your opinion on:
a. The effectiveness of this presentation
b. The instructor's teaching style
c. Classroom conditions

5. Any additional comments you have about this library instruction class

\section{Figure 2}

Library Instruction Survey

Fall 2003

\section{LIBRARY INSTRUCTION SURVEY}

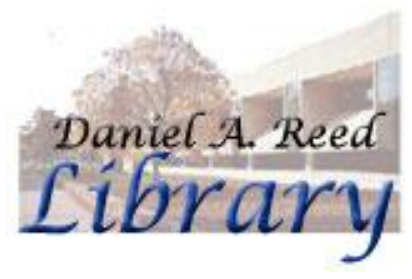

Library Instructor:

Class/Day/Session:

Date: 
1. Are you using the Internet to find research articles?

If yes, which search engine do you use (Yahoo, Google, ...)

1. How important is this library session to your overall academic success?

2. Do you feel more confident about doing a research paper?

3. Will you be able to apply concepts learned today to other research assignments?

4. What is it that you learned today that you didn't know before?

a.

b.

5. Please describe your opinion on:

a. the effectiveness of this presentation

b. the instructor's teaching style

6. Any additional comments you have about this library instruction class 